\title{
A case-control study of benign ovarian tumours
}

\author{
Margaret Booth, Valerie Beral, Noreen Maconochie, Lucy Carpenter, Cherill Scott
}

\begin{abstract}
Study objective-The aim was to investigate the association between reproductive, contraceptive, and menstrual factors and risk of benign ovarian tumours.

Design and setting-This was a casecontrol study carried out in six London Hospitals. An interviewer administered questionnaire was used.

Subjects-62 women with a benign epithelial ovarian neoplasm, 37 women with a functional ovarian cyst, and 20 women with a dermoid cyst presenting between 1983 and 1985 , together with 132 controls, took part in the study.

Main results-On average, women with a benign epithelial ovarian neoplasm were older than those with a functional ovarian cyst, who in turn were older than those with a dermoid cyst. Nulliparity and infertility were associated with an increased risk, and multiparity with a reduced risk, of benign epithelial ovarian neoplasms. Infertility and pelvic inflammatory disease were associated with increased risks of functional and dermoid cysts. Recent use of oral contraceptives was associated with a reduced risk of all three tumour types.

Conclusions-The findings suggest that
\end{abstract} the aetiology of ovarian cysts and benign epithelial ovarian neoplasms may differ. The aetiology of benign and malignant epithelial ovarian neoplasms may be similar, however, since some risk factors are shared. f Epidemiol Community Health 1992; 46: 528-531

Epidemiological Monitoring Unit, London School of Hygiene and Tropical Medicine, Keppel Street, London WC1E 7HT, United Kingdom $M$ Booth

N Maconochie

L Carpenter

C Scott

Imperial Cancer

Research Fund,

Cancer Epidemiology

Unit, University of

Oxford, The Radcliffe

Infirmary, Oxford,

United Kingdom

V Beral

Correspondence to: Dr Booth

Accepted for publication March 1992
Benign ovarian tumours are the fourth most common gynaecological reason for admission to hospital in England and Wales. Most admissions occur between the ages of 15 and 44 years with a peak at ages 25 to 34 years. At these ages about one woman in every 1000 is discharged from hospital each year with a diagnosis of benign ovarian tumour. ${ }^{1}$ Little is known about the causes of these tumours, except that oral contraceptive use has been reported to be associated with a reduced risk of functional ovarian cysts. ${ }^{23}$

We report here the findings of a case-control study of women with a benign ovarian tumour admitted to six London hospitals between 1983 and 1985 . The aim of the study was to investigate the risk factors for these tumours, especially those relating to reproductive history and oral contraceptive use, and to assess whether they vary for the different pathological types of tumour.

\section{Methods}

Between 1983 and 1985, 132 women between the ages of 15 and 64 years who were diagnosed as having a benign ovarian tumour were identified at six London hospitals. The type of lesion was classified from information on the hospital pathology report. The histological type was described as a benign epithelial neoplasm in 61 cases $(46 \%)$, a functional ovarian cyst (follicular, corpus luteum, or other type of functional cyst) in 37 cases $(28 \%)$, a dermoid cyst in 19 cases $(14 \%)$, and a fibroma in five cases $(4 \%)$. One woman had both a benign epithelial neoplasm and a dermoid cyst. There were nine women for whom the type of lesion was unknown or for whom the information was missing. Controls were frequency matched on age to the cases and for each case one control was chosen. The interviewer inspected the ward lists to identify women in the same five year age group $(15-19,20-24 \ldots 60-64$ years) as the cases who had been interviewed at the same hospital. One hundred and thirty two control patients were interviewed. Women were ineligible as controls if they had a condition which has been related to reproductive history or oral contraceptive use, ie, vascular, gynaecological, gallbladder, breast or thyroid disease, rheumatoid arthritis, or melanoma. The controls had been admitted with diseases of the digestive system $(n=28)$, fractures and other inuries (27), diseases of the respiratory system (22), diseases of the musculoskeletal system and connective tissue (19), and various other conditions (36). All cases and controls were interviewed by one trained nurse interviewer. Using the same standard questionnaire as in a previous study of malignant ovarian disease, ${ }^{4}$ each woman was asked detailed questions about her demographic, reproductive, contraceptive, and menstrual history.

\section{DATA ANALYSIS}

Maximum llkelihood estimates of odds ratios, which approximate closely to relative risks, and tests for trend where appropriate were computed using unconditional logistic regression with the GLIM statistical package. ${ }^{56}$ The findings are presented as relative risks (RR) with $95 \%$ confidence intervals $(95 \% \mathrm{CI})$. All tests for significance were two sided. Separate analyses were performed for the cases with a benign epithelial neoplasm, a functional cyst, and a dermoid cyst. The woman with both a benign epithelial neoplasm and a dermoid cyst was included in the analyses for both tumour types. Those with a fibroma or whose tumour type was unknown were too few for analysis and were excluded. All 132 controls were used in the analyses for each tumour type. Esti- 
mates of relative risk were adjusted for age in five year groups. Social class was based on occupation, ${ }^{7}$ using own occupation for women who had never been married and husband's occupation for married women. Nulligravid and gravid defines, respectively, women who had never knowingly conceived and women who had had at least one pregnancy. Parity denotes number of live births and stillbirths.

\section{Results}

The age distribution of the cases by tumour type and of controls is shown in table I. There are clear differences between the cases. On average, women with a benign epithelial neoplasm were the oldest ( 39.6 years) and the women with a dermoid cyst the youngest ( $29 \cdot 2$ years). The social

Table I Age distribution of cases by tumour type and controls

\begin{tabular}{|c|c|c|c|c|c|c|c|c|}
\hline \multirow{3}{*}{$\begin{array}{l}\begin{array}{l}\text { Age group } \\
\text { (years) }\end{array} \\
15-24 \\
25-34 \\
35-44 \\
45-54 \\
55-64 \\
\text { Total }\end{array}$} & \multicolumn{8}{|c|}{ Tumour type } \\
\hline & \multicolumn{2}{|c|}{$\begin{array}{l}\text { Benign epithelial } \\
\text { neoplasm } \\
\text { Cases }(\%)\end{array}$} & \multicolumn{2}{|c|}{$\begin{array}{l}\text { Functional } \\
\text { cyst } \\
\text { Cases }(\%)\end{array}$} & \multicolumn{2}{|c|}{$\begin{array}{l}\text { Dermoid } \\
\text { cyst } \\
\text { Cases }(\%)\end{array}$} & \multicolumn{2}{|c|}{ Controls $(\%)$} \\
\hline & $\begin{array}{r}3 \\
19 \\
22 \\
11 \\
7 \\
62\end{array}$ & $\begin{array}{r}(5) \\
(31) \\
(35) \\
(18) \\
(11) \\
(100)\end{array}$ & $\begin{array}{r}4 \\
14 \\
14 \\
5 \\
-\quad \\
37\end{array}$ & $\begin{array}{r}(11) \\
(38) \\
(38) \\
(14) \\
- \\
(100)\end{array}$ & $\begin{array}{r}8 \\
9 \\
1 \\
1 \\
1 \\
20\end{array}$ & $\begin{array}{r}(40) \\
(45) \\
(5) \\
(5) \\
(5) \\
(100)\end{array}$ & $\begin{array}{r}15 \\
45 \\
42 \\
20 \\
10 \\
132\end{array}$ & $\begin{array}{r}(11) \\
(34) \\
(32) \\
(15) \\
(8) \\
(100)\end{array}$ \\
\hline Average age (SD) (years): & \multicolumn{2}{|c|}{$39 \cdot 6(9 \cdot 75)$} & \multicolumn{2}{|c|}{$35 \cdot 2(9 \cdot 13)$} & \multicolumn{2}{|c|}{$29 \cdot 2(9 \cdot 38)$} & \multicolumn{2}{|c|}{$37 \cdot 1(10 \cdot 86)$} \\
\hline
\end{tabular}

class distribution of the cases and controls was similar, with $39 \%, 43 \%$, and $13 \%$, of the cases and $38 \%, 44 \%$, and $13 \%$ of the controls in social classes I-II, III, and, IV-V respectively. Five percent of cases and controls could not be allocated to a social class. There were three cases and three controls who had never been sexually active and these women have been excluded from analyses of reproductive history and contraceptive use.

For benign epithelial neoplasms, increased risks of borderline statistical significance were associated with nulligravidity $(R R=2 \cdot 2,95 \% \mathrm{CI}$ $1 \cdot 0-5 \cdot 1)$ and nulliparity ( $R R=2 \cdot 2,95 \%$ CI $1 \cdot 0-4 \cdot 8)$, the risks decreasing as parity increased $\left[\chi^{2}\right.$ (trend) $\left.=6.8, p<0.01\right]$ (table II). The risks for dermoid cysts associated with these aspects of pregnancy history showed a similar pattern to those for benign epithelial neoplasms although none was statistically significant. There was no evidence of an association between any of the three tumour types and history of spontaneous or induced abortion or with age at first birth.

Having been investigated for infertility was associated with an increased risk of all three tumour types (table III). These risks were significantly raised for women with a benign epithelial neoplasm ( $R R=4 \cdot 3,95 \%$ CI $1 \cdot 6-11 \cdot 1)$ and a functional cyst $(R R=4 \cdot 0,95 \%$ CI $1 \cdot 3-12 \cdot 1)$. For these two tumour types, the risks were increased among both nulligravid and gravid women. Adjusting for infertility did not affect the relative risk estimates associated with pregnancy history shown in table II.

Associations with oral contraceptive use are shown in table IV. The relative risk of benign epithelial neoplasms was increased by the use of oral contraceptives, the duration of use, and the discontinuation of use more than six months before interview, but the increase was not statistically significant. The previous use of oral contraceptives at any time was associated with a reduced risk of dermoid cyst, the risk decreasing with increasing duration of use $\left[\chi^{2}\right.$ (trend) $=10 \cdot 5$, $\mathrm{p}<0.01$ ]. In women who had been using oral contraceptives in the six months prior to interview (recent use) there was a reduction in the relative risk of occurrence of all three tumour types, but not reaching statistical significance. Other methods of contraception were not related to risk of any of the tumour types.

Table $\mathrm{V}$ shows data relating to menarche, menstruation, and pelvic infection. Women who reported menarche later than 12 years had a reduced risk of a benign epithelial neoplasm $(\mathrm{RR}=0 \cdot 4,95 \% \mathrm{CI} 0 \cdot 2-0 \cdot 8, \mathrm{p}<0 \cdot 01)$. There were no clear associations with other aspects of menstruation although, as compared to the controls, women in all three tumour groups were less likely to have very irregular periods but more likely to have periods which were often painful. Those reporting previous pelvic infection had an increased risk of functional cysts $(R R=4 \cdot 6,95 \%$ CI 1.8-11.1, p $<0.001)$ and a non-significantly increased risk of dermoid cysts $(R R=3 \cdot 0,95 \% C I$ 0.9-9.9). Six of the eight women with a functional
Table II Relative risks $(R R)$ for benign ovarian tumours associated with pregnancy history

(sexually active women only)

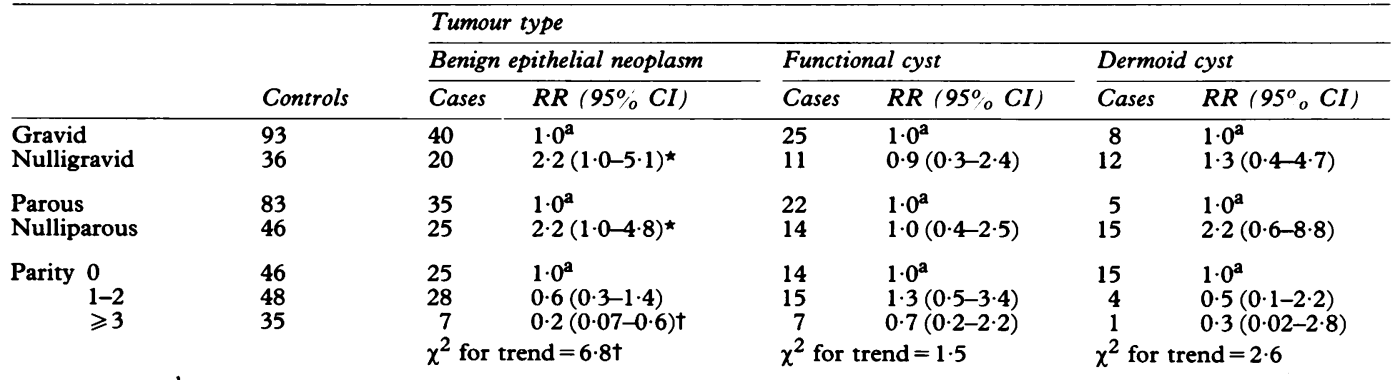

\begin{tabular}{|c|c|c|c|c|c|c|c|}
\hline $\begin{array}{c}\text { Total abortions }^{b} \\
\quad 0 \\
\geqslant 1\end{array}$ & $\begin{array}{l}94 \\
35\end{array}$ & $\begin{array}{l}45 \\
15\end{array}$ & $\begin{array}{l}1 \cdot 0^{\mathrm{a}} \\
0 \cdot 8(0 \cdot 4-1 \cdot 6)\end{array}$ & $\begin{array}{l}25 \\
11\end{array}$ & $\begin{array}{l}1 \cdot 0^{\mathrm{a}} \\
1 \cdot 3(0 \cdot 6-3 \cdot 1)\end{array}$ & $\begin{array}{r}15 \\
5\end{array}$ & $\begin{array}{l}1 \cdot 0^{\mathrm{a}} \\
1 \cdot 6(0 \cdot 5-5 \cdot 7)\end{array}$ \\
\hline $\begin{array}{l}\text { Age at first } \\
\text { livebirth (years) } \\
\quad<20 \\
\quad \geqslant 20\end{array}$ & $\begin{array}{l}22 \\
61\end{array}$ & $\begin{array}{r}6 \\
29\end{array}$ & $\begin{array}{l}1 \cdot 0^{\mathrm{a}} \\
1 \cdot 3(0 \cdot 4-4 \cdot 3)\end{array}$ & $\begin{array}{r}9 \\
13\end{array}$ & $\begin{array}{l}1 \cdot 0^{\mathrm{a}} \\
0 \cdot 3(0 \cdot 1-1 \cdot 0)\end{array}$ & $\begin{array}{l}1 \\
4\end{array}$ & $\begin{array}{l}1 \cdot 0^{\mathrm{a}} \\
1 \cdot 1(0 \cdot 1-12 \cdot 3)\end{array}$ \\
\hline
\end{tabular}

All relative risks adjusted for age

All relative risks adjuste

beference category

${ }^{c}$ Relative risks adjusted additionally for number of livebirths

${ }^{\star} p \leqslant 0.05 ; \mathrm{tp}<0.01$ 
Table III Relative risks (RR) for benign ovarian tumours associated with infertility (sexually active women only).
Table IV Relative risks $(R R)$ for benign ovarian tumours associated with oral contraceptive use (sexually active women only).

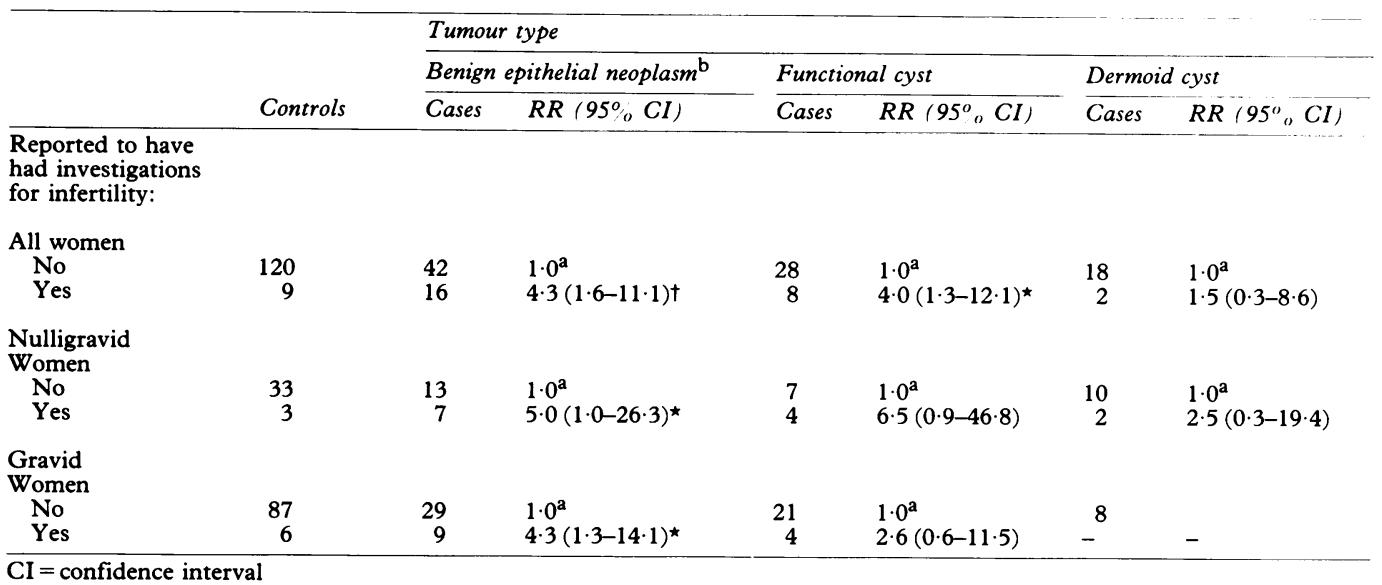

All relative risks adjusted for age

${ }^{\text {a Reference category }}$

Excludes two gravid women referred from infertility clinic ${ }^{\star} \mathrm{p} \leqslant 0.05,+\mathrm{p}<0.01$

cyst who reported having investigations for infertility had also had previous pelvic infection.

\section{Discussion}

The interviewer visited all six hospitals each week to identify women who had been given a diagnosis of benign ovarian tumour. While it is possible that a few cases may have been missed (most likely during holiday times) any such loss will have been small. It is improbable, therefore, that the final study population will have been biased in any way as compared to all women admitted to these hospitals with benign ovarian tumours over the period of the investigation.

The risk of a benign epithelial ovarian neoplasm was increased among sexually active women who had never conceived or who had never had a live birth or stillbirth. For these tumours there was also a significant trend of decreasing risk with increasing parity. These results are consistent with those reported for cystadenomas of the ovary $^{3}$ and for benign epithelial ovarian cysts. ${ }^{8}$ We also found that women with a benign epithelial neoplasm were significantly more likely to have had previous investigations for infertility. These risk factors for benign epithelial neoplasms are similar to those found for malignant epithelial neoplasms. ${ }^{4}$

The findings of Vessey et $a l^{3}$ were similar to ours insofar as cystadenomas and functional cysts were less common among women who had used oral contraceptives in the six months preceding diagnosis. Neither previous use of oral contraceptives at any time nor duration of use was associated with decreased risks of benign epithelial ovarian neoplasms, in contrast with findings for malignant ovarian disease which have shown that oral contraceptives reduced the risk of ovarian cancer; the longer the use the lower the risk. ${ }^{9}$

Having been investigated for infertility and having had pelvic inflammatory disease were both associated with an increased risk of a functional cyst and a (non-significantly) increased risk of a dermoid cyst. Since pelvic inflammatory disease is associated with infertility, ${ }^{10}$ analyses were repeated adjusting each variable for the other. The magnitude and significance of each of the risks persisted. An association between pelvic inflammatory disease and ovarian cysts has been noted before in a study of hospital admissions for pelvic inflammation in England and Wales. ${ }^{11}$ Of women admitted to hospital with pelvic inflammatory disease, $3.4 \%$ also had an ovarian cyst, compared to $0.8 \%$ of women undergoing sterilisation (unpublished data).

Women with a benign epithelial neoplasm were, on average, older than those with a functional cyst, who in turn were older than those with a dermoid cyst. The difference in the age distributions and the finding of relatively few consistent associations with the variables studied suggests that benign epithelial ovarian neoplasms, functional ovarian cysts, and dermoid cysts may

\begin{tabular}{|c|c|c|c|c|c|c|c|}
\hline \multirow{3}{*}{$\begin{array}{l}\text { Oral contraceptive } \\
\text { use }\end{array}$} & \multirow[b]{3}{*}{ Controls } & \multicolumn{6}{|c|}{ Tumour type } \\
\hline & & \multicolumn{2}{|c|}{ Benign epithelial neoplasm } & \multicolumn{2}{|c|}{ Functional cyst } & \multicolumn{2}{|c|}{ Dermoid cyst } \\
\hline & & $\overline{\text { Cases }}$ & $R R(95 \% C I)$ & $\overline{\text { Cases }}$ & $R R(95 \% C I)$ & Cases & $R R\left(95^{\circ} C I\right)$ \\
\hline $\begin{array}{l}\text { Never used } \\
\text { Ever used }\end{array}$ & $\begin{array}{l}38 \\
91\end{array}$ & $\begin{array}{l}18 \\
42\end{array}$ & $\begin{array}{l}1 \cdot 0^{\mathrm{a}} \\
1 \cdot 4(0 \cdot 6-3 \cdot 5)\end{array}$ & $\begin{array}{r}8 \\
28\end{array}$ & $\begin{array}{l}1 \cdot 0^{\mathrm{a}} \\
1 \cdot 0(0 \cdot 3-2 \cdot 7)\end{array}$ & $\begin{array}{r}7 \\
13\end{array}$ & $\begin{array}{l}1 \cdot 0^{\mathrm{a}} \\
0 \cdot 2(0.04-0 \cdot 8)^{\star}\end{array}$ \\
\hline $\begin{array}{l}\text { Duration of use } \\
\text { Never } \\
<5 \text { years } \\
\geqslant 5 \text { years }\end{array}$ & $\begin{array}{l}38 \\
51 \\
40\end{array}$ & $\begin{array}{l}18 \\
19 \\
23 \\
\gamma^{2}\end{array}$ & $\begin{array}{l}1 \cdot 0^{\mathrm{a}} \\
1 \cdot 1(0.4-3 \cdot 1) \\
1 \cdot 7(0.6-4.5)\end{array}$ & $\begin{array}{l}8 \\
17 \\
11 \\
\gamma^{2}\end{array}$ & $\begin{array}{l}1 \cdot 0^{\mathbf{a}} \\
1 \cdot 0(0 \cdot 3-3 \cdot 1) \\
0 \cdot 9(0 \cdot 3-2 \cdot 8)\end{array}$ & $\begin{array}{r}7 \\
8 \\
5 \\
\gamma^{2}\end{array}$ & $\begin{array}{l}1 \cdot 0^{\mathrm{a}} \\
0 \cdot 3(0 \cdot 03-1 \cdot 3) \\
0.04(0.003-0.4) \ddagger \\
\text { en }=10.5 t\end{array}$ \\
\hline
\end{tabular}

\begin{tabular}{llllllrr} 
Timing of use $^{\mathrm{b}}$ & & & & & 1 & \\
$\quad$ Never used & 38 & 18 & $1 \cdot 0^{\mathrm{a}}$ & 8 & $1 \cdot 0^{\mathrm{a}}$ & 7 & $1 \cdot 0^{\mathrm{a}}$ \\
Recent use & 65 & 3 & $0 \cdot 4(0 \cdot 07-1 \cdot 9)$ & 4 & $0 \cdot 3(0 \cdot 06-1 \cdot 5)$ & 1 & $0 \cdot 1(0 \cdot 01-0 \cdot 6)^{\star}$ \\
Past use & 26 & 39 & $1 \cdot 5(0 \cdot 6-3 \cdot 6)$ & 24 & $1 \cdot 0(0 \cdot 4-2 \cdot 9)$ & 12 & $0 \cdot 3(0 \cdot 05-1 \cdot 2)$ \\
\hline
\end{tabular}

$\mathrm{CI}=$ confidence interval

All relative risks adjusted for age and parity

a Reference group

Reference group
Recent use $=$ use in the six months before interview

Past use = no use in the six months before interview

${ }_{\star} \mathrm{p} \leqslant 0.05 ; \mathrm{tp}<0.01 ; \neq \mathrm{p}<0.001$ 
Table $V$ Relative risks ( $R R$ ) for benign ovarian tumours associated with menarche, menstruation and pelvic infection.

\begin{tabular}{|c|c|c|c|c|c|c|c|}
\hline & \multirow[b]{3}{*}{ Controls } & \multicolumn{6}{|c|}{ Tumour type } \\
\hline & & \multicolumn{2}{|c|}{ Benign epithelial neoplasm } & \multicolumn{2}{|c|}{ Functional cyst } & \multicolumn{2}{|c|}{ Dermoid cyst } \\
\hline & & Cases & $R R(95 \% C I)$ & Cases & $R R(95 \% C I)$ & Cases & $R R\left(95^{\circ}{ }_{o} C I\right)$ \\
\hline $\begin{array}{l}\text { Age at menarche } \\
<12 \text { years } \\
\geqslant 12 \text { years } \\
\text { Not known }\end{array}$ & $\begin{array}{r}21 \\
109 \\
2\end{array}$ & $\begin{array}{r}18 \\
42 \\
2\end{array}$ & $\begin{array}{l}1 \cdot 0^{\mathrm{a}} \\
0 \cdot 4(0 \cdot 2-0 \cdot 8) \dagger\end{array}$ & $\begin{array}{r}8 \\
29 \\
-\end{array}$ & $\begin{array}{l}1 \cdot 0^{\mathrm{a}} \\
0 \cdot 6(0 \cdot 2-1 \cdot 7)\end{array}$ & $\begin{array}{r}3 \\
16 \\
1\end{array}$ & $\begin{array}{l}1 \cdot 0^{\mathrm{a}} \\
1 \cdot 7(0 \cdot 9-3 \cdot 4)\end{array}$ \\
\hline $\begin{array}{l}\text { Menstruation } \\
\text { Regular } \\
\text { Sometimes irregular } \\
\text { Very irregular } \\
\text { Not known }\end{array}$ & $\begin{array}{r}86 \\
26 \\
19 \\
1\end{array}$ & $\begin{array}{r}50 \\
9 \\
3 \\
-\end{array}$ & $\begin{array}{l}1 \cdot 0^{\mathrm{a}} \\
0 \cdot 6(0 \cdot 3-1 \cdot 5) \\
0 \cdot 3(0.08-1 \cdot 1)\end{array}$ & $\begin{array}{r}23 \\
10 \\
4 \\
-\end{array}$ & $\begin{array}{l}1 \cdot 0^{\mathrm{a}} \\
1 \cdot 2(0 \cdot 4-4 \cdot 0) \\
0 \cdot 7(0 \cdot 2-2 \cdot 5)\end{array}$ & $\begin{array}{r}12 \\
7 \\
1 \\
-\end{array}$ & $\begin{array}{l}1 \cdot 0^{\mathrm{a}} \\
1 \cdot 2(0.4-3 \cdot 9) \\
0 \cdot 3(0.03-2 \cdot 4)\end{array}$ \\
\hline $\begin{array}{l}\text { Never painful } \\
\text { Sometimes painful } \\
\text { Often painful }\end{array}$ & $\begin{array}{l}79 \\
33 \\
20\end{array}$ & $\begin{array}{l}29 \\
22 \\
11\end{array}$ & $\begin{array}{l}1.0^{\mathrm{a}} \\
2 \cdot 1(1 \cdot 0-4 \cdot 5)^{\star} \\
1 \cdot 8(0.7-4 \cdot 6)\end{array}$ & $\begin{array}{r}17 \\
7 \\
13\end{array}$ & $\begin{array}{l}1 \cdot 0^{\mathrm{a}} \\
1 \cdot 0(0 \cdot 4-2 \cdot 6) \\
3 \cdot 1(1 \cdot 2-7 \cdot 8)^{\star}\end{array}$ & $\begin{array}{l}6 \\
5 \\
9\end{array}$ & $\begin{array}{l}1 \cdot 0^{\mathbf{a}} \\
1 \cdot 0(0 \cdot 3-4 \cdot 1) \\
3 \cdot 9(1 \cdot 1-14 \cdot 0)^{\star}\end{array}$ \\
\hline $\begin{array}{l}\text { Previous pelvic } \\
\text { infection } \\
\text { No } \\
\text { Yes }\end{array}$ & $\begin{array}{r}112 \\
20\end{array}$ & $\begin{array}{r}55 \\
7\end{array}$ & $\begin{array}{l}1.0^{\mathrm{a}} \\
0 \cdot 7(0 \cdot 3-1 \cdot 9)\end{array}$ & $\begin{array}{l}20 \\
15\end{array}$ & $\begin{array}{l}1 \cdot 0^{\mathrm{a}} \\
4 \cdot 6(1 \cdot 8-11 \cdot 1) \ddagger\end{array}$ & $\begin{array}{r}14 \\
6\end{array}$ & $\begin{array}{l}1 \cdot 0^{\mathrm{a}} \\
3 \cdot 0(0 \cdot 9-9 \cdot 9)\end{array}$ \\
\hline
\end{tabular}

$\mathrm{CI}=$ confidence interval

All relative risks adjusted for age

${ }^{2}$ Reference group

${ }^{\star} \mathrm{p} \leqslant 0.05 ;$ †0.01; $\neq \mathrm{p}<0.001$

well have different aetiologies. Certain risk factors are shared for benign and malignant epithelial ovarian neoplasms. This suggests either that the aetiology of the two conditions is similar or that benign epithelial ovarian neoplasms may be precursors of malignant disease. In this study, the average age of those with a benign epithelial ovarian tumour was 39.6 years while in our study of malignant epithelial ovarian cancer, the average age of the cases was 52.4 years. ${ }^{4}$ Thus, considering latency, it is not inconceivable that benign epithelial ovarian tumours could be precursors of ovarian cancer. There is, however, no evidence from case-control studies that this is so.

We would like to thank the consultants, nurses, and other staff of the participating hospitals for their help and support of the study, Chris Wale for computing assistance and Evelyn Middleton for typing help.
1 Westhoff CL, Beral V. Patterns of ovarian cyst hospital discharge rates in England and Wales, 1962-79. BMF 1984; 289: 1348-9.

2 Ory H. Functional ovarian cysts and oral contraceptives. Negative association confirmed surgically. $\mathcal{F} A M A$ 1974; 228: 68-9.

3 Vessey M, Metcalfe A, Wells C, McPherson K, Westhoff, C Yeates D. Ovarian neoplasms, fuctional ovarian cysts, and oral contraceptives. BMF 1987; 294: 1518-20.

4 Booth M, Beral V, Smith P. Risk factors for ovarian cancer: a case-control study. $B r F$ Cancer 1989; 60: 592-8. epidemiological research. Case-control studies. Sydney: The Intstat Foundation for Statistical Data Analysis, 1982.

6 Payne CD, ed. The Glim system release 3.77 manual-edition 2. Oxford: Numerical Algorithms Group, 1987.

7 Office of Population Censuses and Surveys. Classification of occupations. London: HMSO, 1970.
Orfice

8 Parrazzini F, La Vecchia C, Franceschi S, Negri E, Parrazzini F, La Vecchia C, Franceschi S, Negri E, serous benign ovarian cysts. Int $\mathcal{f}$ Epidemiol 1989; 18 108-12.

9 Booth M, Beral V. The epidemiology of ovarian cancer. In: Hudson CN, ed. Ovarian cancer. Oxford: Oxford University Press, 1985: 22-44.

10 Westrom, L. Effect of acute pelvic inflammatory disease on fertility. Am $\mathcal{F}$ Obstet Gynecol 1975; 121: 707-13.

11 Robinson N, Beral V, Ashley JSA. Trends in pelvic inflammatory disease in England and Wales. 7 Epidemio Commuity Health 1981; 35: 265-70.
5 Adena MA, Wilson SR. Generalised linear models in 